\title{
MARKETING VIRAL: MAPEAMENTO DA PRODUÇÃO CIENTÍFICA NA BIBLIOTECA ELETRÔNICA SPELL
}

\section{VIRAL MARKETING: AN ANALYSIS OF SCIENTIFIC PRODUCTION IN THE SPELL ELECTRONIC LIBRARY}

\author{
Alex Eckert \\ Universidade de Caxias do Sul, RS - UCS \\ alex.eckert@bol.com.br
}

Débora Thiel

Universidade de Caxias do Sul, RS - UCS

dthiel1@ucs.br

Submissão: $17 / 08 / 2018$

Aprovação: 24/05/2019

\begin{abstract}
RESUMO
O marketing viral pode se constituir de um meio eficaz pelo qual as organizações se aproximam de seu público-alvo e conquistam seguidores de sua marca, propagando seu conteúdo de maneira exponencial. Nesse contexto, o presente estudo teve por objetivo identificar as principais características das publicações sobre o tema disponibilizadas na biblioteca eletrônica Spell. Para atingir esse objetivo, elaborou-se uma pesquisa bibliométrica, de caráter exploratório e qualitativo. Como resultado, identificou-se que o marketing viral é essencialmente fundamentado em conteúdos de entretenimento, engajando seus receptores a compartilhar, gerando emoções como alegria e surpresa, sendo que o principal objetivo da maioria dos usuários, no momento em que compartilham, é aumentar sua própria influência e melhorar sua imagem.
\end{abstract}

Palavras-chave: Marketing viral. Bibliometria. Base Spell.

\begin{abstract}
Viral marketing is an effective way in which organizations get close to their target audience and win followers of their brand, spreading their content exponentially. In this context, the present study aimed to identify the main characteristics of viral marketing publications available in the Spell electronic library. To achieve this goal, an exploratory and qualitative research was developed through a bibliometry. As a result, it has been identified that viral marketing is essentially based on entertainment content, engaging its recipients to share, generating emotions such as joy and surprise, and the main goal of most of these users, in the moment they share, is to increase their own influence and improve their image.
\end{abstract}

Keywords: Viral Marketing. Bibliometry. Spell electronic library. 


\section{Introdução}

A Internet rompeu as barreiras do espaço e do tempo, criando inúmeras ferramentas digitais e ampliando o alcance da web por meio da IoT - Internet of Things (Internet das Coisas), se tornando cada vez mais popular e acessível às pessoas (SOUZA; GIGLIO, 2015). Prova disso é que a internet faz parte da vida de $59 \%$ dos brasileiros, segundo publicado pela Empresa Brasil de Comunicação em outubro de 2017, sendo que o Brasil é o quarto país em número de usuários da internet com 120 milhões de pessoas conectadas à web, atrás apenas dos Estados Unidos, Índia e China (VALENTE, 2017).

Antes do surgimento da internet, a comunicação mercadológica via rádio e televisão, por exemplo, valia-se de um modelo baseado na interrupção da programação e de programas patrocinados por anunciantes. Com o passar dos anos, essa sistemática invasiva passou a se desestabilizar, inicialmente pela própria proliferação de canais, e depois pela concorrência provocada pela internet. Embora o modelo tradicional, considerado por muitos como invasivo, não tenha desaparecido, este precisou investir na sedução do consumidor por outros meios, estimulando-se o chamado consumo de experiências, composto pela interação das lógicas de entretenimento, sociáveis e corporativas, no qual se tem compartilhado conteúdo em um volume jamais visto e de maneira progressiva (CASTRO, 2012).

A era digital se caracteriza como tendência mundial à conectividade por meio da internet e o declínio das mídias tradicionais corroboram estas grandes mudanças. Previsões de empresas de consultoria, como por exemplo a McKinsey \& Company, indicam que os investimentos em mídias digitais estão em franca expansão (BAGCHI; MURDOCH; SCANLAN, 2015). Visto isso, surge uma grande oportunidade para as organizações utilizarem o marketing digital como sua principal fonte de comunicação com seus consumidores. Além disso, se pode identificar que um grande potencial está concentrado nos conteúdos em formato de vídeos, mais dinâmicos e possibilitando maior interação entre os usuários. A chave para o sucesso digital está na humanização das marcas e no engajamento gerado nos consumidos para compartilhar seu conteúdo.

Assim, o presente estudo tem por objetivo realizar o mapeamento da produção científica sobre o tema marketing viral na base de dados Spell - Scientific Periodicals Eletronic Library, identificando os atributos destes artigos e interligando suas descobertas para enfim traçar um perfil de características e os achados destas publicações, contribuindo para o entendimento deste tema ainda pouco abordado cientificamente no Brasil.

\section{Referencial Teórico}

\subsection{Evolução do Marketing}

Conforme Pinheiro e Gullo (2013) a internet vem transformando o mundo de maneira exponencial e tem alavancado o desenvolvimento da inteligência coletiva, estimulando a colaboração entre as pessoas. As empresas necessitam acompanhar estas transformações geradas principalmente pela geração $\mathrm{Y}$, tendo em vista que ela representará $50 \%$ da força de trabalho em poucos anos, a qual possui um perfil preocupado em gerar menor desperdício, com conceitos de sucesso diferentes dos tradicionais, considerando o espírito de colaboração global.

As estratégias de marketing devem contemplar quatro elementos tradicionais conhecidos como 4 Ps do marketing: 1) Produto - bem tangível ou intangível com a finalidade de satisfazer necessidades e/ou desejos; 2) Preço - formulado considerando posicionamento de mercado, valor ao cliente, preço aplicado pelos concorrentes, margem de lucro e custos de 
produção; 3) Praça ou ponto de venda - caminho pelo qual a empresa chega ao consumidor, oferecendo conveniência e buscando estabelecer uma relação duradoura; 4) Promoção - forma pela qual a organização se comunica com seu mercado (REICHELT, 2013; KOTLER; KARTAJAYA; SETIAWAN, 2017).

O marketing evoluiu ao longo dos anos em diversas fases, sendo nomeadas como: Marketing 1.0 - com foco no produto e no mercado em massa; Marketing 2.0 - com foco no consumidor e na segmentação do mercado; e o Marketing 3.0 - com foco no ser humano e seus anseios por um mundo melhor (KOTLER; KARTAJAYA; SETIAWAN, 2010). Para uma melhor compreensão dessas fases e respectivas características, elaborou-se a Tabela 1, apresentada na sequência.

Tabela 1 - Características do Marketing 1.0, 2.0 e 3.0

\begin{tabular}{|c|c|c|c|}
\hline & $\begin{array}{l}\text { Marketing } 1.0 \\
\text { Marketing centrado no } \\
\text { produto }\end{array}$ & $\begin{array}{l}\text { Marketing 2.0 Marketing } \\
\text { voltado para o consumidor }\end{array}$ & $\begin{array}{l}\text { Marketing 3.0 Marketing } \\
\text { voltado para os valores }\end{array}$ \\
\hline Objetivo & Vender produtos & $\begin{array}{l}\text { Satisfazer e reter os } \\
\text { consumidores }\end{array}$ & $\begin{array}{l}\text { Fazer do mundo um lugar } \\
\text { melhor }\end{array}$ \\
\hline Forças propulsoras & Revolução industrial & Tecnologia da informação & Nova onda de tecnologia \\
\hline $\begin{array}{l}\text { Como as empresas veem o } \\
\text { mercado }\end{array}$ & $\begin{array}{l}\text { Compradores de massa, com } \\
\text { necessidades físicas }\end{array}$ & $\begin{array}{l}\text { Consumidor inteligente, } \\
\text { dotado de coração e mente }\end{array}$ & $\begin{array}{l}\text { Ser humano pleno, com } \\
\text { coração, mente e espírito }\end{array}$ \\
\hline Conceito de marketing & $\begin{array}{l}\text { Desenvolvimento de } \\
\text { produto }\end{array}$ & Diferenciação & Valores \\
\hline $\begin{array}{l}\text { Diretrizes de marketing da } \\
\text { empresa }\end{array}$ & Especificação do produto & $\begin{array}{l}\text { Posicionamento do produto } \\
\text { e da empresa }\end{array}$ & $\begin{array}{l}\text { Missão, visão e valores da } \\
\text { empresa }\end{array}$ \\
\hline Proposições de valor & Funcional & Funcional e emocional & $\begin{array}{l}\text { Funcional, emocional e } \\
\text { espiritual }\end{array}$ \\
\hline $\begin{array}{l}\text { Interação com } \\
\text { consumidores }\end{array}$ & $\begin{array}{l}\text { Transação do tipo um-para- } \\
\text { um }\end{array}$ & $\begin{array}{l}\text { Relacionamento um-para- } \\
\text { um }\end{array}$ & $\begin{array}{l}\text { Colaboração um-para- } \\
\text { muitos }\end{array}$ \\
\hline
\end{tabular}

Fonte: KOTLER; KARTAJAYA; SETIAWAN (2010, p. 17)

Considerando a Tabela 1, pode-se interpretar que as organizações se voltaram gradativamente do produto para as pessoas e seu meio ambiente, enaltecendo o relacionamento com seus clientes, destacando seus princípios e valores. Kotler, Kartajaya e Setiawan $(2010$, p. 34) já previam que a evolução do marketing teria sua continuidade, considerando "as mudanças no ambiente de negócios - recessão, preocupações com o meio ambiente, novas mídias sociais, empowerment do consumidor, nova onda de tecnologia e globalização".

\subsection{Marketing 4.0}

A revolução digital é uma das mais significativas influências sobre as modificações no comportamento do consumidor, às quais estão acontecendo de forma exponencial (ECKERT, 2017). A rápida transmissão de informação entre consumidor e empresa aumenta a interação entre eles e as demandas dos usuários devem ser atendidas com uma urgência muito maior. A globalização alterou o conceito de comunidade, rompeu as barreiras de tempo e distância, gerando comunidades cada vez mais heterogêneas, com demandas específicas (SOLOMON, 2011).

Pinheiro e Gullo (2013, p. 61) definem a internet como "uma rede de computadores, através das quais as pessoas buscam informação, diversão, lazer, relacionamento e comunicação", o que possibilita interatividade e agilidade nas relações sociais e no mundo empresarial. As ferramentas mais utilizadas na era Web 3.0 são os e-mails, sites, blogs, redes 
sociais, fóruns, buscadores, chats (como por exemplo, o whatsapp), virtual, colaborativo código aberto, banner - pop-up e marketing viral.

A internet possibilita grande conexão e transparência em nossas vidas, mudando de modo drástico as estruturas de poder até então conhecidas. Desta forma, as forças inclusivas e sociais (denominadas de forças horizontais) passaram a superar as forças exclusivas e individuais (denominadas como forças verticais). A relação entre os consumidores e a marca deve ser construída por meio de uma "amizade", esforços conjuntos na elaboração de soluções e de maneira à marca demonstrar honestamente seu caráter e propósito (KOTLER; KARTAJAYA; SETIAWAN, 2017).

Considerando o Marketing 4.0, os 4 Ps se reinventaram passando aos 4 Cs: co-criation (co-criação), currency (moeda), communal activation (ativação comunitária) e conversation (conversa). A co-criação consiste em uma nova estratégia de concepção de produtos com a participação de seus consumidores, o que aumenta a taxa de sucesso, possibilitando a customização e personalização dos mesmos. A moeda, ou precificação, estabelece a flexibilização dos preços conforme demandas e capacidades de utilização. A ativação comunitária estabelece a distribuição ponto a ponto, onde as empresas oferecem serviços que são de propriedade da comunidade próxima aos clientes, agilizando o atendimento às suas necessidades. A conversa possibilita aos consumidores reagirem às mensagens recebidas pela marca, oferecendo avaliações, interagindo com outros consumidores (KOTLER; KARTAJAYA; SETIAWAN, 2017).

Os brasileiros já destinam mais tempo navegando na internet do que assistindo televisão e esta é uma grande oportunidade para os empreendedores, apesar de não saberem exatamente de que forma aproveitar esta nova era do mercado (LIRA, 2016). Com a evolução para o Marketing 4.0, os Ps do marketing também sofreram interferência de um novo ponto de vista e, conforme Vaz (2011), o marketing digital é composto por 8 Ps em um processo circular em torno do consumidor, norteando as organizações quanto à:

- Pesquisa: conhecer as demandas dos consumidores e realizar ações focadas no meio digital;

- Planejamento: por meio de um planejamento de marketing digital criam-se planos de ação visando realizar um trabalho de maior eficácia;

- Produção: realizar e controlar para que as ações ocorram conforme estipulado;

- Publicação: disponibilizar o conteúdo ao público-alvo visando proporcionar interesse em compartilhar, trazendo visibilidade à marca e/ou produto;

- Promoção: Comunicar ao público-alvo por meio de conteúdo útil e até inspiracional;

- Propagação: etapa na qual o conteúdo ganha credibilidade e em que a empresa deve investir em impulsionar ainda mais seu compartilhamento;

- Personalização: Criar conteúdos específicos para cada perfil de consumidor, tendo uma campanha de marketing mais assertiva;

- Precisão: por meio de métricas, verificar os conteúdos que tiveram sucesso e buscar aprendizado para replica-lo em novas ações de marketing da organização.

Uma estratégia de grande sucesso dentro do marketing 4.0 está na humanização das marcas, tendo em vista que esta era está centrada no ser humano, suas ansiedades, desejos latentes, netnografia (etnografia on-line) e pesquisa empática. Kotler, Kartajaya e Setiawan (2017, p. 143) ainda explicam que "elas devem ser fisicamente atraentes, intelectualmente interessantes, socialmente envolventes e emocionalmente fascinantes, ao mesmo tempo em que devem demonstrar personalidade forte e moralidade sólida". 


\subsection{Conteúdo Viral}

Segundo o estudo de Berger e Milkman (2012) os conteúdos que geram emoções, sendo elas positivas ou negativas, ocasionam impulsos fisiológicos de excitação, estimulando sua viralização. Os autores também identificaram que, independente de sua valência, os conteúdos positivos (que geram diversão, sendo surpreendentes e bem humorados) são sempre mais virais que os negativos (que geram tristeza, ansiedade ou raiva).

Botha e Reyneke (2013) reforçam as afirmações de Berger e Milkman em seu estudo no ano seguinte, afirmando que para compartilhar conteúdo com seus familiares e amigos, os receptores da mensagem precisam estar conectados emocionalmente com o material a ser difundido. Tendo em vista essa realidade, é necessário fazer alguns questionamentos no momento da criação de conteúdos que tem o objetivo de se tornarem virais, como se pode observar na Figura 1:

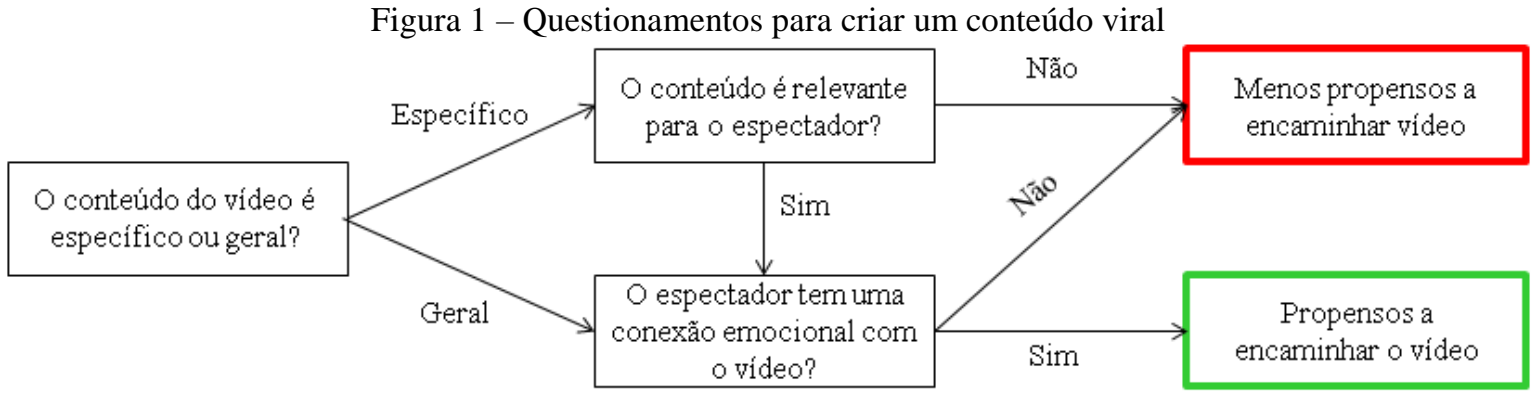

Fonte: Adaptado de BOTHA; REYNEKE (2013, p. 168).

A Figura 1 guia os criadores de conteúdo para a propagação viral de seu material, considerando que o mesmo é determinado por dois filtros principais: o conteúdo é geral ou específico? Em ambos os casos, o conteúdo precisa ter conexão emocional e relevância para o receptor o compartilhar. Com tudo, se concluiu que as emoções são essenciais para o compartilhamento de conteúdos e que este "contágio emocional" resulta nos compartilhamentos em massa que caracterizam o conteúdo viral.

Nas poucas palavras de Berger (2014, p. 14), "se conseguirem fazer com que as pessoas falem de sua ideia ou compartilhem seu conteúdo, isso irá se espalhar pelas redes sociais como um vírus, tornando o produto ou ideia instantaneamente popular ao longo do processo".

\subsection{Marketing Viral}

Torres (2010) define o efeito viral como a transmissão inicial de um conteúdo a um conjunto de pessoas definidos como usuários alpha, que se sentem estimulados a compartilham este conteúdo para duas ou mais pessoas, de forma a ter uma resposta exponencial de alcance de público.

O termo "viralizar" tem sido cada vez mais utilizado entre os profissionais envolvidos nas divulgações e promoções das empresas, tendo em vista que se tornou de senso comum o grande impacto que as campanhas que exploram o marketing viral têm e os retornos positivos que causa. O grande diferencial desta estratégia está na velocidade de propagação do conteúdo e a grande audiência que conquista, quando que o mesmo promoverá a marca, direta ou indiretamente. Características que podem facilitar este efeito de propagação viral são campanhas criativas, engajadoras e impactantes que explorem esta espontaneidade nos consumidores de compartilhar a mensagem (LAM, 2013). 
Segundo o estudo desenvolvido por Ho e Dempsey (2010), se identificou que os usuários de internet adultos com perfil individualista e/ou altruísta tendem ao compartilhamento e disseminação de conteúdo com maior facilidade, este estudo considerou como hipóteses principais o sentimento de pertencimento a um grupo (netnografia), a busca pelo individualismo, pelo altruísmo e ainda objetivando crescimento pessoal.

Arcos, Gutierrez e Hernanz (2014) identificaram por meio de diversos estudos acadêmicos que o marketing viral e suas aplicações têm diversos pontos considerados vantajosos e outros que trazem desvantagens, como pode ser verificado na Tabela 2.

Tabela 2 - Vantagens e Desvantagens do Marketing Viral

\begin{tabular}{|c|c|}
\hline \multicolumn{2}{|c|}{ Marketing Viral } \\
\hline Vantagens & Desvantagens \\
\hline $\begin{array}{l}\text { Baixo valor de investimentos (custos) necessários para } \\
\text { desenvolver uma campanha }\end{array}$ & $\begin{array}{l}\text { Relativa falta de controle sobre a mensagem e sua } \\
\text { distribuição, dependendo da localização }\end{array}$ \\
\hline Capacidade de atingir um grande número de pessoas & $\begin{array}{l}\text { Possíveis alterações na mensagem ao longo da cadeia de } \\
\text { difusão }\end{array}$ \\
\hline $\begin{array}{l}\text { A informação é transmitida e propagada de forma fácil e } \\
\text { rápida }\end{array}$ & Bloqueio de mensagens por proteções contra vírus e spam \\
\hline $\begin{array}{l}\text { Alcance dos grupos de consumidores geograficamente } \\
\text { dispersos }\end{array}$ & $\begin{array}{l}\text { Pode ser percebido como uma invasão nas redes sociais dos } \\
\text { usuários }\end{array}$ \\
\hline Flexibilidade em conteúdos e formatos & Dificuldade do planejamento da campanha \\
\hline $\begin{array}{l}\text { Aumento exponencial no envio de mensagens pelos } \\
\text { usuários de forma voluntária }\end{array}$ & $\begin{array}{l}\text { O uso inadequado do marketing viral pode ser prejudicial, } \\
\text { criando atitudes desfavoráveis em relação a uma empresa, } \\
\text { marca ou produto }\end{array}$ \\
\hline $\begin{array}{l}\text { Melhoria no alcance do público-alvo, uma vez que aqueles } \\
\text { que encaminham mensagens sabem quem de seus } \\
\text { conhecidos estará mais relacionado à leitura e aceitação de } \\
\text { sua mensagem }\end{array}$ & $\begin{array}{l}\text { A insatisfação com a empresa, marca ou produto pode se } \\
\text { multiplicar com os efeitos negativos no boca-boca }\end{array}$ \\
\hline Aceleração da adoção do produto & $\begin{array}{l}\text { Dificuldade de criar uma mensagem viral que motive os } \\
\text { clientes a enviá-lo }\end{array}$ \\
\hline $\begin{array}{l}\text { Maior credibilidade e confiabilidade de opiniões on-line do } \\
\text { que em outras estratégias de comercialização ou anúncios } \\
\text { tradicionais }\end{array}$ & $\begin{array}{l}\text { Dificuldade em identificar pessoas-chave em redes sociais } \\
\text { que vão adotar um produto e promovê-lo entre seus } \\
\text { conhecidos }\end{array}$ \\
\hline $\begin{array}{l}\text { Efetividade maior do que outras estratégias de marketing } \\
\text { ou anúncios tradicionais }\end{array}$ & $\begin{array}{l}\text { Risco de certos usuários serem pagos pelas empresas para } \\
\text { difundir suas mensagens }\end{array}$ \\
\hline Melhorar o conhecimento do produto, marca ou empresa & $\begin{array}{l}\text { Os fatores que motivam a aceitação e difusão da } \\
\text { informação podem variar de acordo com as pessoas }\end{array}$ \\
\hline $\begin{array}{l}\text { Melhoria no posicionamento do produto, marca ou empresa } \\
\text { na rede }\end{array}$ & $\begin{array}{l}\text { Poucos usuários encaminham mensagens de comerciais } \\
\text { para seus contatos }\end{array}$ \\
\hline Possível medição do resultado da campanha em tempo real & $\begin{array}{l}\text { Percepção de menor qualidade e credibilidade das } \\
\text { informações on-line }\end{array}$ \\
\hline $\begin{array}{l}\text { Aumento da influência na decisão de compra do } \\
\text { consumidor }\end{array}$ & $\begin{array}{l}\text { Os destinatários podem não aceitar as recomendações de } \\
\text { outros }\end{array}$ \\
\hline
\end{tabular}




\begin{tabular}{l|l}
$\begin{array}{l}\text { Você obtém informações sobre os consumidores e } \\
\text { interagem com eles }\end{array}$ & Dificuldade em avaliar a efetividade da campanha \\
\hline O efeito perdura ao longo do tempo através da Internet & Não é adequado para certas empresas, marcas e/ou produtos \\
\hline
\end{tabular}

Fonte: Adaptado de ARCOS; GUTIÉRREZ; HERNANZ (2014, p. 20-21).

Segundo Mans (2017) em sua entrevista com o professor Jonah Berger, o conteúdo que viraliza é uma ciência, na qual se baseia em uma combinação conhecida como STEPPS e composta por seis características: moeda social (mensagens que façam as pessoas se sentirem especiais quando compartilham), gatilhos (associações entre coisas geram mais boca a boca), emoção (ações que mexam com os sentimentos das pessoas), público (ser reconhecido pelas suas ideias), valor prático (conteúdo útil) e histórias (narrativas que envolvem). Por fim, ressalta que o conteúdo não deve estar diretamente ligado à venda, pois haverá grandes chances de gerar reações negativas.

Conforme Daraya (2013) inicialmente se tinha conhecimento apenas de que o ritmo de compartilhamento e um determinado perfil de usuário eram essenciais para o sucesso da viralização de um conteúdo. A partir disso, um grupo de cientistas militares dos Estados Unidos desenvolveu um algoritmo para escanear as redes em busca deste perfil de usuário com a quantidade certa de amigos, com este procedimento conseguiram definir a "semente" de um determinado grupo que tem o primeiro contato com o conteúdo e o distribui instantaneamente pela internet.

\section{Aspectos Metodológicos}

O estudo desenvolvido adotou como procedimentos técnicos a pesquisa bibliográfica, que se realiza tradicionalmente por intermédio de análise de documentações, fazendo uso de revistas, livros, jornais, teses, dissertações e anais de eventos científicos, buscando autores e verificando a produção de estudos anteriores sobre o tema em foco (GIL, 2010; CASARIN, 2012).

Considerando Casarin (2012), se pode classificar o método de pesquisa utilizado, quanto aos seus objetivos, como exploratório, pois tem como base a investigação de um determinado assunto, buscando um maior conhecimento por meio de revisões de leitura. Malhotra (2012) explica que as pesquisas exploratórias têm por finalidade: a) levantar um problema e/ou o definir com maior precisão; b) investigar ações alternativas; c) levantar hipóteses; d) examinar relações e variáveis de maneiras isoladas; e) apurar informações que auxiliem no desenvolvimento para abordar o problema.

A abordagem do problema de pesquisa deste estudo se caracteriza como qualitativa, pois aplica sua análise por meio de metodologia descritiva, relacionando as informações com outros fatores e buscando associações que possam contribuir para explicar o que está sendo pesquisado, sendo que suas principais características são: subjetividade, multiplicidade, interpretação, narração, coleta de dados e análise de dados (CASARIN, 2012). Segundo Perovano (2016), modelos de análise de dados qualitativos não possuem regras rígidas, porém torna-se necessário uma codificação de dados sistemática e deve ser planejada de modo a possibilitar que se inicie ainda no momento da coleta de dados em campo.

A bibliometria foi a ferramenta aplicada para o desenvolvimento deste estudo e se originou da busca por medir quantidades de exemplares, edições, palavras contidas em obras, apurar os espaços destinados para os livros em bibliotecas, entre outras métricas. Com o aperfeiçoamento da ferramenta e novas demandas, a bibliometria passou a ser aplicada para analisar outros formatos bibliográficos produzidos, estendendo-se aos artigos, periódicos, 
anais, entre outros documentos, e por fim aplicando ao levantamento da produção dos autores e estudando citações (ARAÚJO, 2006).

Os estudos voltados aos aspectos quantitativos da produção e disseminação das informações científicas são classificados como bibliometria, na qual adquire maior flexibilidade e consistência quando considerado analise geográfica e de redes (FRANCISCO, 2011). Ribeiro (2013) explica que existem três leis básicas aplicadas na bibliometria: Lotka (relacionada com a produção científica dos autores), Zipf (relacionada à frequência das palavras) e Bradford (relacionada com a produção de periódicos científicos), tendo sido esta última a utilizada para a elaboração deste trabalho.

\section{Realização da Pesquisa}

A base de dados utilizada para a realização deste estudo foi a Spell - Scientific Periodicals Eletronic Library, a qual se autodenomina um repositório de artigos científicos e proporciona acesso gratuito à informação técnico-científica, sendo que a mesma informava, no momento em que se realizou esta pesquisa, disponibilizar em seu acervo 44.337 documentos. A Spell é uma base de dados brasileira criada em 2012, na qual concentra a produção científica das áreas de Administração, Contabilidade e Turismo, publicadas a partir de 2008 (SPELL, 2018).

Quando da realização da pesquisa, optando pela pesquisa avançada, se buscou o termo marketing viral como título do documento, resumo ou palavra-chave, apenas em artigos da área da Administração, o que resultou em oito documentos para análise bibliográfica. Não foi determinado o período de publicações, considerando todos os documentos inseridos na Spell, desde sua criação em 2012, até agosto de 2018. Em termos de ferramentas, utilizou-se uma planilha no software Microsoft Excel® 2010, possibilitando assim armazenar as informações dos documentos e realizar as análises almejadas.

Nesta planilha, distribuíram-se entre as colunas os seguintes itens de análise: Sigla, Título, Ano da Publicação, Periódico da Publicação, ISSN, Instituição, Referência, Quantidade de Autores, Tipo de Referencial Utilizado - Revista, Referencial Utilizado Livro, Referencial Utilizado - Web, Referencial Utilizado - Dissertações, Referencial Utilizado - Teses, Referencial Utilizado - Eventos, Referencial Utilizado - Total, Método de Pesquisa - Procedimentos Técnicos, Método de Pesquisa - Objetivos, Método de Pesquisa Abordagem, Técnica de Coleta de Dados, Objetivos do Estudo e Resultados Encontrados.

\section{Apresentação dos Dados e Análise}

Conforme descrito no tópico anterior, a amostra definitiva para a realização da pesquisa foi de oito artigos. Para facilitar a visualização e caracterização, estes foram organizados sequencialmente, apresentando o seu título, ano de publicação, nome do periódico, ISSN, autoria e respectivo vínculo institucional, conforme Quadro 1.

Quadro 1 - Artigos sobre Marketing Viral na base Spell

\begin{tabular}{|c|c|c|c|c|c|c|}
\hline ID & Título & $\begin{array}{c}\text { Ano da } \\
\text { Publicação }\end{array}$ & $\begin{array}{c}\text { Periódico da } \\
\text { Publicação }\end{array}$ & ISSN & $\begin{array}{c}\text { Instituição de } \\
\text { vínculo dos } \\
\text { autores }\end{array}$ & Referência \\
\hline A1 & $\begin{array}{c}\text { Fatores de impacto no } \\
\text { sucesso do marketing } \\
\text { boca a boca on-line }\end{array}$ & 2002 & $\begin{array}{c}\text { RAE - Revista de } \\
\text { Administração de } \\
\text { Empresas }\end{array}$ & $\begin{array}{c}\text { FGV-EAESP } \\
\text { Escola de } \\
7590\end{array}$ & $\begin{array}{c}\text { Administração } \\
\text { de Empresas de } \\
\text { São Paulo }\end{array}$ & $\begin{array}{c}\text { BENTIVEGNA, } \\
\text { Fernando Jucá. }\end{array}$ \\
\hline
\end{tabular}




\begin{tabular}{|c|c|c|c|c|c|c|}
\hline A2 & $\begin{array}{l}\text { O uso do Youtube } \\
\text { como ferramenta de } \\
\text { marketing: o caso } \\
\text { Guaraná Antarctica }\end{array}$ & 2009 & $\begin{array}{c}\text { Revista } \\
\text { Pensamento } \\
\text { Contemporâneo } \\
\text { em Administração }\end{array}$ & $\begin{array}{l}1982- \\
2596\end{array}$ & $\begin{array}{l}\text { Universidade } \\
\text { Federal } \\
\text { Fluminense }\end{array}$ & $\begin{array}{c}\text { PEREIRA, Thiago } \\
\text { Carvalho; } \\
\text { CRUZ, Eduardo } \\
\text { Picanço. }\end{array}$ \\
\hline A3 & $\begin{array}{c}\text { Elaboração e } \\
\text { experimento de um } \\
\text { método de marketing } \\
\text { viral e database } \\
\text { marketing baseado em } \\
\text { algoritmos genéticos }\end{array}$ & 2012 & $\begin{array}{c}\text { Revista Gestão \& } \\
\text { Tecnologia }\end{array}$ & $\begin{array}{l}2177- \\
6652\end{array}$ & $\begin{array}{l}\text { Centro } \\
\text { Universitário de } \\
\text { Belo Horizonte }\end{array}$ & $\begin{array}{c}\text { BORGES, Fábio } \\
\text { Roberto Ferreira; } \\
\text { GONÇALVES, } \\
\text { Carlos Alberto; } \\
\text { VEIGA, Ricardo } \\
\text { Teixeira; } \\
\text { GOSLING, } \\
\text { Marlusa; } \\
\text { FERNANDES, } \\
\text { Izabella Bueno. }\end{array}$ \\
\hline A4 & $\begin{array}{c}\text { Propagação de } \\
\text { mensagens na } \\
\text { internet: teoria do } \\
\text { comportamento } \\
\text { planejado }\end{array}$ & 2012 & Revista Pretexto & $\begin{array}{l}1517- \\
672 x\end{array}$ & $\begin{array}{l}\text { Universidade } \\
\text { Federal de } \\
\text { Minas Gerais }\end{array}$ & $\begin{array}{l}\text { SOUZA, Gustavo } \\
\text { Ferreira Mendes de; } \\
\text { BORGES, Fábio } \\
\text { Roberto Ferreira; } \\
\text { LOPES, Ana Lucia } \\
\text { Miranda; MUNIZ, } \\
\text { Reynaldo Maia. }\end{array}$ \\
\hline A5 & $\begin{array}{l}\text { Comunicações de } \\
\text { marketing de } \\
\text { fabricantes de } \\
\text { alimentos: quando o } \\
\text { alvo são crianças e a } \\
\text { mídia internet }\end{array}$ & 2012 & $\begin{array}{c}\text { Revista Gestão \& } \\
\text { Tecnologia }\end{array}$ & $\begin{array}{l}2177- \\
6652\end{array}$ & $\begin{array}{c}\text { Centro } \\
\text { Universitário da } \\
\text { FEI } \\
\text { FGV-EAESP } \\
\text { Escola de } \\
\text { Administração } \\
\text { de Empresas de } \\
\text { São Paulo } \\
\text { Faculdade de } \\
\text { Informática e } \\
\text { Administração - } \\
\text { FIAP, UNIP }\end{array}$ & $\begin{array}{l}\text { HUERTAS, Melby } \\
\text { Karina Zuniga; } \\
\text { URDAN, André } \\
\text { Torres; ADACHI, } \\
\text { Patricia Podboi; } \\
\text { GOMES, Silvia } \\
\text { Cressoni. }\end{array}$ \\
\hline A6 & $\begin{array}{l}\text { Bots sociais: como } \\
\text { robôs podem se tornar } \\
\text { influentes no Twitter }\end{array}$ & 2015 & $\begin{array}{c}\text { Revista Eletrônica } \\
\text { de Sistemas de } \\
\text { Informação }\end{array}$ & $\begin{array}{l}1677- \\
3071\end{array}$ & $\begin{array}{l}\text { Universidade } \\
\text { Federal de Ouro } \\
\text { Preto }\end{array}$ & $\begin{array}{c}\text { MESSIAS, } \\
\text { Johnnatan; } \\
\text { SCHMIDT, Lucas; } \\
\text { OLIVEIRA, } \\
\text { Ricardo; } \\
\text { BENEVENUTO, } \\
\text { Fabrício. }\end{array}$ \\
\hline A7 & $\begin{array}{l}\text { "Engaja-me e atraia- } \\
\text { me, então eu } \\
\text { compartilharei”: uma } \\
\text { análise do impacto da } \\
\text { categoria da postagem } \\
\text { no marketing viral em } \\
\text { uma rede social }\end{array}$ & 2016 & $\begin{array}{c}\text { RBGN - Revista } \\
\text { Brasileira de } \\
\text { Gestão de } \\
\text { Negócios }\end{array}$ & $\begin{array}{l}1806- \\
4892\end{array}$ & $\begin{array}{l}\text { Universidade } \\
\text { Federal de } \\
\text { Goiás }\end{array}$ & $\begin{array}{l}\text { ALMEIDA, Marcos } \\
\text { Inácio Severo de; } \\
\text { COSTA, Milena; } \\
\text { COELHO; Ricardo } \\
\text { Limongi França; } \\
\text { SCALCO, Paulo } \\
\text { Roberto. }\end{array}$ \\
\hline
\end{tabular}




\begin{tabular}{|c|c|c|c|c|c|c|}
\hline \multirow[t]{2}{*}{ A8 } & \multirow{2}{*}{$\begin{array}{l}\text { Contagious content: } \\
\text { viral video ads } \\
\text { identification of } \\
\text { content characteristics } \\
\text { that help online video } \\
\text { advertisements go } \\
\text { viral }\end{array}$} & \multirow[t]{2}{*}{2016} & \multirow[t]{2}{*}{$\begin{array}{l}\text { ReMark - Revista } \\
\text { Brasileira de } \\
\text { Marketing }\end{array}$} & \multirow[t]{2}{*}{$\begin{array}{c}2177- \\
5184\end{array}$} & $\begin{array}{c}\text { International } \\
\text { Communication } \\
\text { and Media pelo } \\
\text { Erasmus } \\
\text { Universiteit } \\
\text { Rotterdam, } \\
\text { Holanda. } \\
\end{array}$ & \multirow[t]{2}{*}{$\begin{array}{c}\text { KNOSSENBURG, } \\
\text { Yentl Lisanne; } \\
\text { NOGUEIRA, Roberto; } \\
\text { CHIMENTI, Paula. }\end{array}$} \\
\hline & & & & & $\begin{array}{l}\text { Universidade } \\
\text { Federal do Rio } \\
\text { de Janeiro }\end{array}$ & \\
\hline
\end{tabular}

Fonte: Elaborado pelos autores

Os artigos resultantes da busca na base Spell foram identificados (ID) de A1 a A8, sendo que o título de cada artigo foi organizado na segunda coluna, em ordem crescente de publicação, todos foram publicados em revistas brasileiras, apresentou-se o ISSN para melhor identificação das revistas, foram descritas todas as instituições que participaram da elaboração dos artigos e por fim as referências dos autores.

Já na Figura 2, se podem visualizar graficamente os anos de publicação dos artigos. Percebe-se que o tema marketing viral é novo em termos de publicações, dos oito artigos resultantes, seis artigos foram publicados nos últimos cinco anos, representando $75 \%$ do volume de publicações. O primeiro artigo foi publicado no ano de 2002, quinze anos antes da realização desta pesquisa, o segundo artigo foi publicado somente sete anos após e a partir de 2012 as publicações ficaram mais constantes, sendo que no último ano publicaram-se dois artigos.

Figura 2 - Ano de publicação

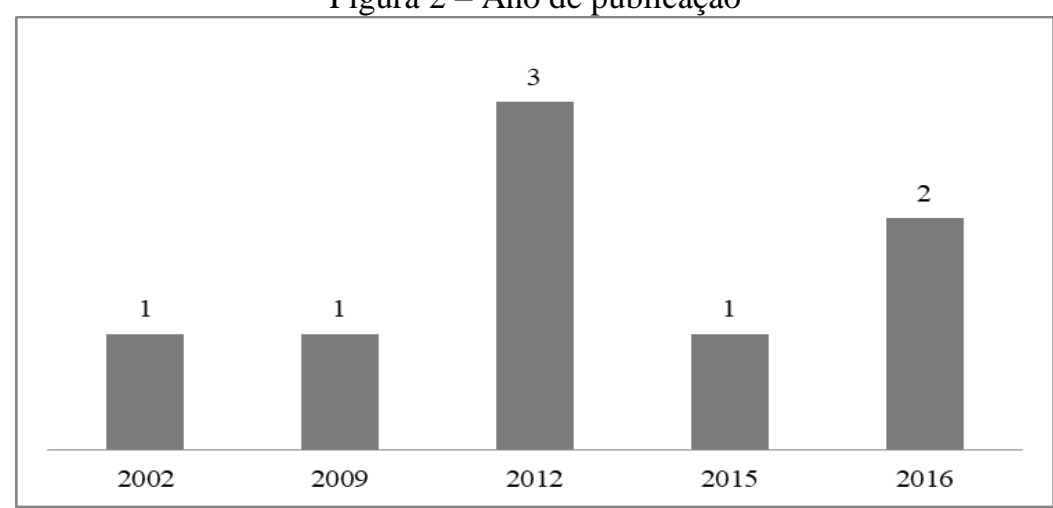

Fonte: Elaborado pelos autores

Neste estudo optou-se por considerar todas as instituições envolvidas nos artigos analisados. Nas Figuras 3 e 4 pode-se visualizar, respectivamente, a quantidade de instituições participantes por artigo e o número de artigos produzidos por instituição. 
Figura 3 - Quantidade de instituições envolvidas na autoria

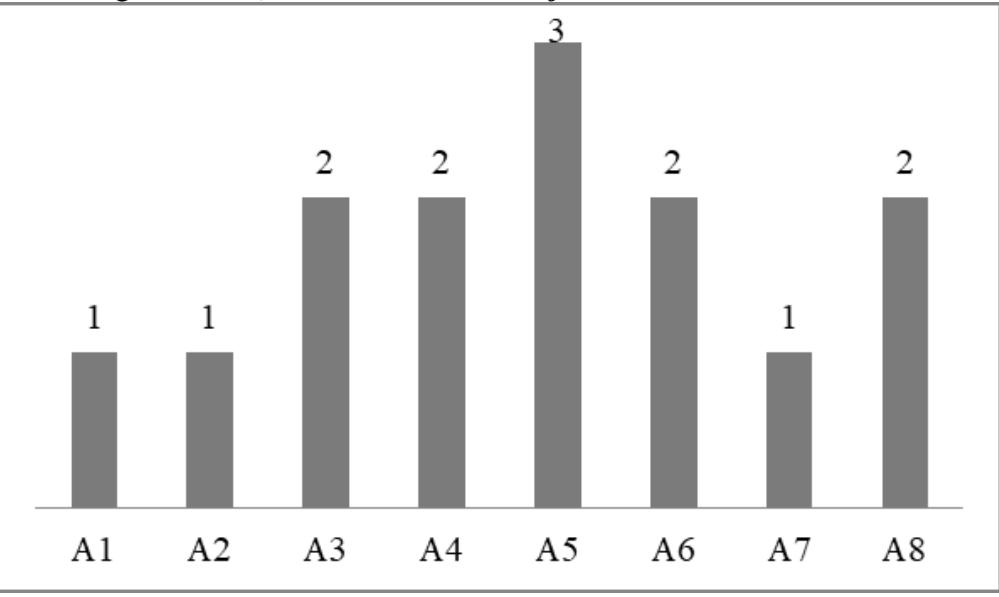

Fonte: Elaborado pelos autores

Figura 4 - Quantidades de artigos por instituição

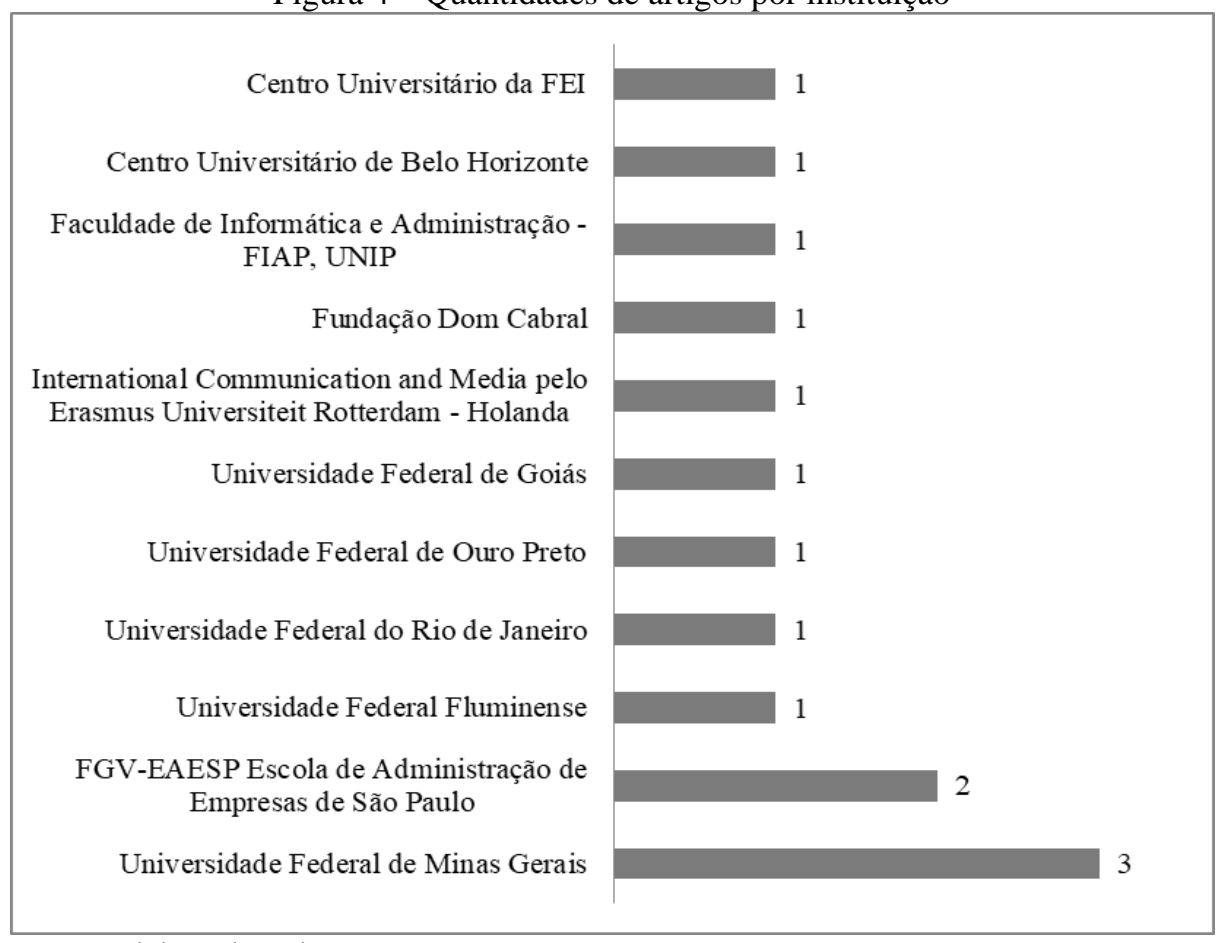

Fonte: Elaborado pelos autores

Os artigos analisados tiveram uma média de 1,75 instituições em sua formulação, considerando que $50 \%$ dos artigos analisados foram construídos com a participação de duas instituições, demonstrando como as instituições tem buscado a conjunção de esforços na elaboração de artigos científicos. Em 37,5\% dos casos, os artigos foram formulados por apenas uma instituição e em $12,5 \%$, somente um artigo, houve a interação de três instituições para elaborar o artigo.

Em sua maioria, os artigos foram desenvolvidos de maneira inédita por estas instituições, apenas a FGV-EAESP Escola de Administração de Empresas de São Paulo teve participação em dois artigos e a Universidade Federal de Minas Gerais teve a maior participação, totalizando três artigos.

Quanto à natureza das instituições participantes, as privadas representam 54,5\%, totalizando seis artigos, enquanto que as públicas representam 45,5\%, totalizando cinco 
artigos. Considerando que o desempate foi ocasionado pela única instituição internacional participante desta análise, a Erasmus Universiteit Rotterdam da Holanda, pode-se dizer que a produção nacional de artigos científicos sobre este tema está equilibrada. Outro ponto a destacar é que a produção nacional está concentrada nas regiões Sudeste e Centro-Oeste do Brasil.

$\mathrm{Na}$ formulação dos artigos analisados, os autores utilizaram diversas fontes de informação, e, para melhor entendimento do perfil geral das referências aplicadas, elaborou-se a Figura 5 .

Figura 5 - Tipos de referencial utilizado considerando todos os artigos

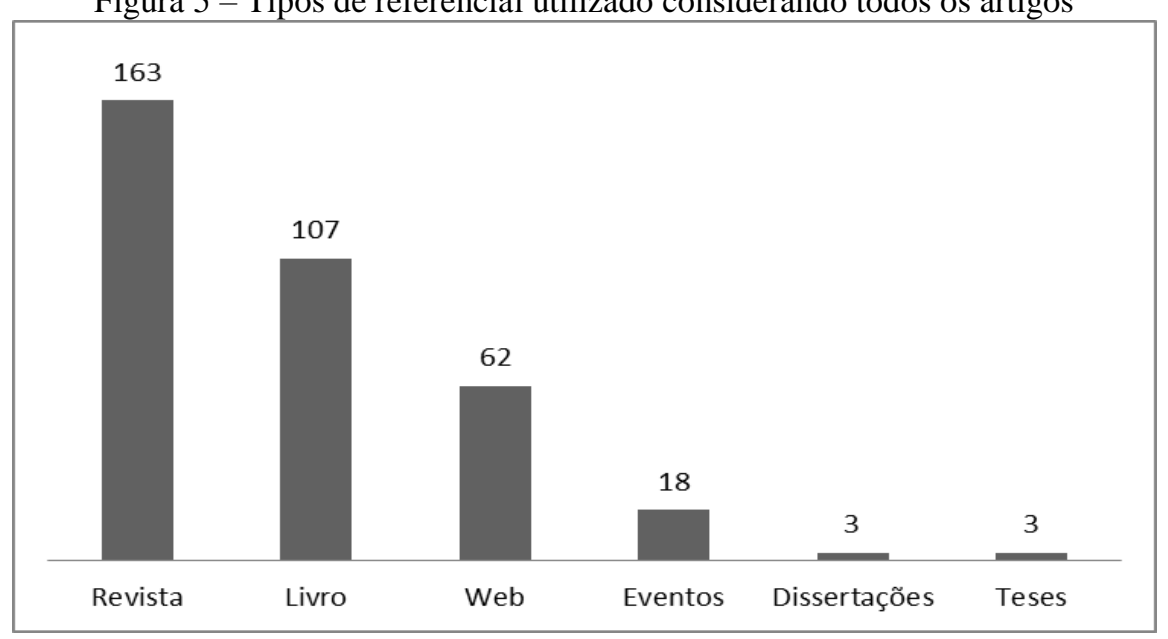

Fonte: Elaborado pelos autores

As revistas lideraram a quantidade de referências utilizadas com $45,79 \%$, os segundos a liderar são os livros com $30,05 \%$, sites da web foram utilizados em $17,42 \%$, eventos foram citados em $5,06 \%$, dissertações e teses foram citadas em $0,84 \%$ cada.

Por meio destes dados, pode-se considerar a solidez e confiabilidade dos livros perante o passar dos anos, porém existe uma crescente tendência na utilização de revistas, supõe-se que pelas publicações serem atualizadas em maior velocidade do que os livros. Além disso, Rodgers e Thorson (2017) explicam que a maior contribuição das revistas está na grande diversidade de tópicos explorados sob uma cobertura de anúncios interativos, colaborando positivamente para o corpo literário.

Por fim, é importante destacar que a partir do ano de 2015 os autores passaram a utilizar publicações de eventos em seus referenciais. Para identificação das referências utilizadas em cada artigo, segue Figura 6. 
Figura 6 - Tipos de referencial utilizado considerando cada artigo

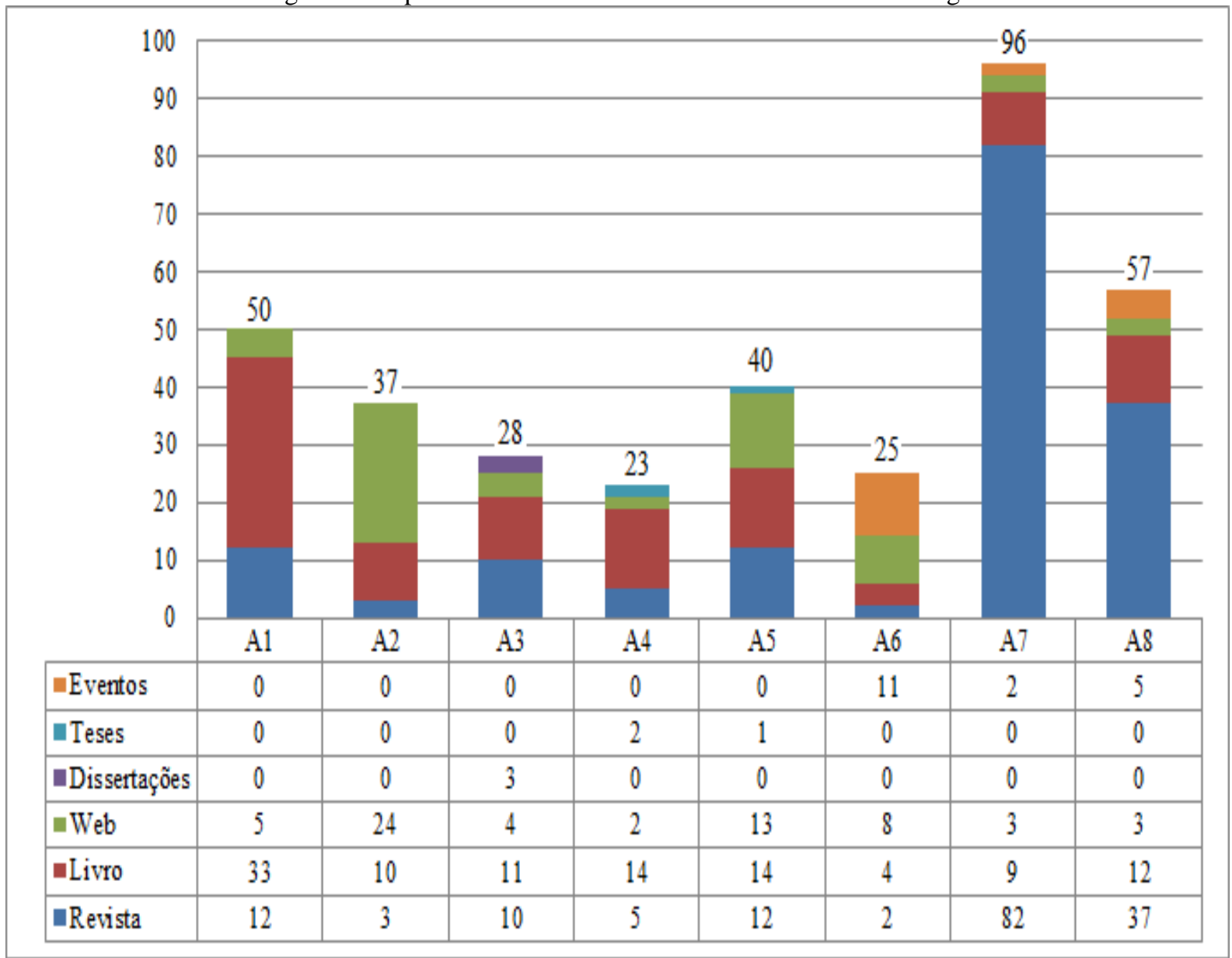

Fonte: Elaborado pelos autores

No artigo A1, utilizou-se predominantemente 33 livros, em segundo plano ficaram as revistas com 12 exemplares citados e por fim cinco sítios da web, totalizando 50 referências. No artigo A2, os autores utilizaram 24 sítios da web, 10 livros e 3 revistas, totalizando 37 referências. O artigo A3 utilizou 11 livros, 10 revistas, 4 sítios da web e 3 dissertações, totalizando 28 referências. Utilizou-se no Artigo A4 um total de 23 referências, sendo composto por 14 livros, 5 revistas, 2 sítios da web e 2 teses.

Já para a formulação do artigo A5, foram utilizados 14 livros, 13 sítios da web, 12 revistas e 1 tese, compondo assim 40 referenciais. No artigo A6 as referências foram compostas por 11 eventos, 8 sítios na web, 4 livros e 2 revistas, num total de 25 . As referências do artigo A7 contemplam 82 revistas, 9 livros, 3 sítios na web e 2 eventos, totalizando 96 referências. Por fim, no artigo A8 observou-se um total de 57 referências, compostas por 37 revistas, 12 livros, 5 eventos e 3 sítios da web.

Conforme Cooper e Schindler (2013), uma pesquisa científica deve ser guiada por um método científico, seguindo procedimentos sistemáticos, incluindo base empírica, gerando pesquisas passíveis de reprodução, considerando seu escopo e contendo um alinhamento de como a pesquisa será conduzida. Uma melhor visualização dos métodos de pesquisa utilizados é apresentada na Figura 7. 
Figura 7 - Métodos de pesquisa utilizados nos artigos

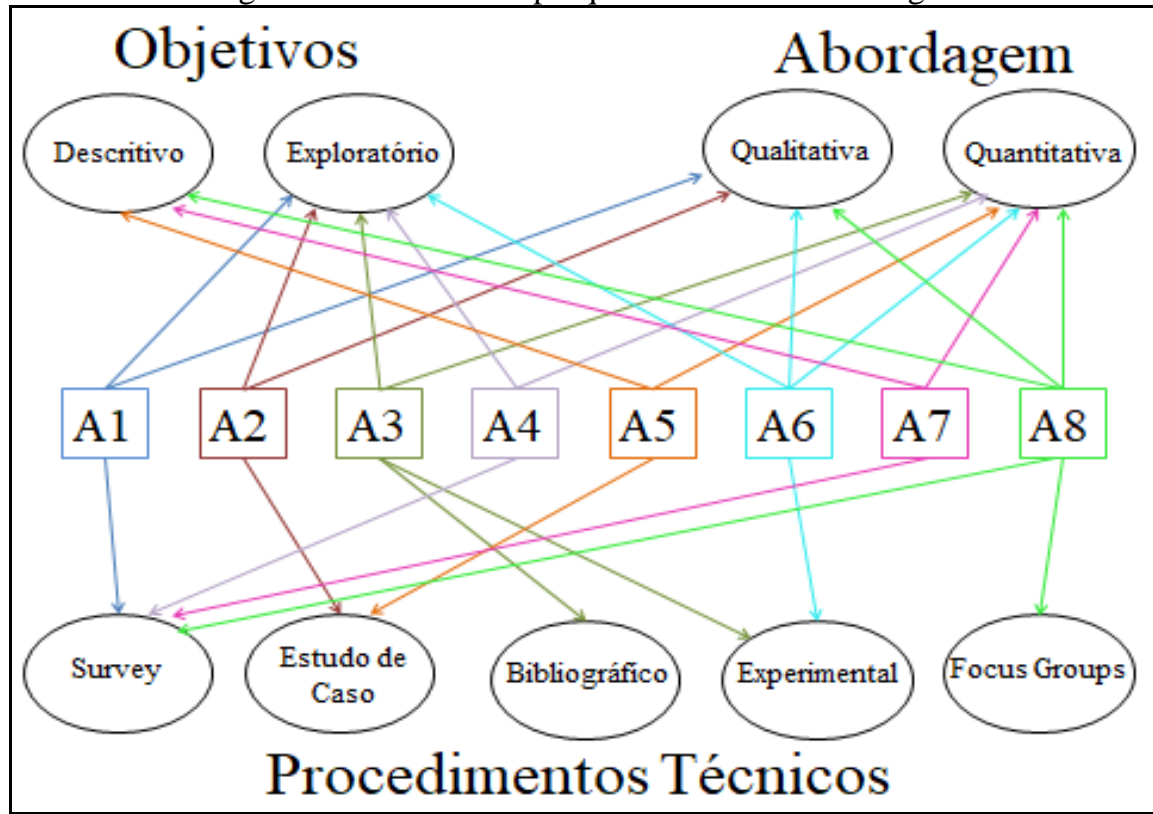

Fonte: Elaborado pelos autores

Os métodos de procedimentos técnicos obtiveram predominância em survey em 37,5\% (três artigos), na sequência obtiveram-se dois estudos de caso, representando $25 \%$ e os artigos restantes apresentaram casos únicos de procedimentos bibliográfico-experimental, surveyfocus groups e experimental, representando $12,5 \%$ cada. Os métodos utilizados tendo em vista os objetivos dos artigos foram predominantemente exploratórios, em cinco artigos $(62,5 \%)$, enquanto que os três restantes foram descritivos $(37,5 \%)$.

Por fim considerou-se o método de abordagem utilizado, onde quatro artigos utilizaram a abordagem quantitativa (50\%), dois artigos utilizaram a abordagem qualitativa $(25 \%)$ e dois utilizaram os dois métodos, conhecidos como abordagem quali-quantitativa (25\%). A Figura 8 a seguir demonstra da distribuição das técnicas de coleta de dados utilizadas pelos autores:

Figura 8 - Técnicas de coleta de dados

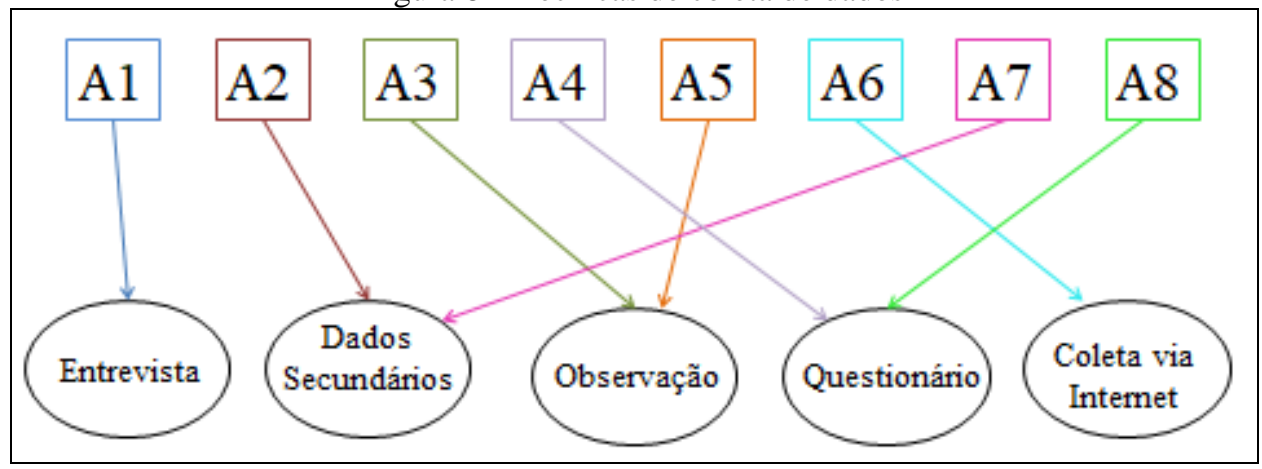

Fonte: Elaborado pelos autores

A técnica de coleta de dados foi bem distribuída, considerando que os dados secundários, observação e questionário obtiveram dois artigos cada $(25 \%)$ e a entrevista e a coleta via internet ocorreram em um artigo cada $(12,5 \%)$.

Para finalizar as análises, os objetivos e os resultados encontrados nos artigos da amostra estão expostos no Quadro 2.

Quadro 2 - Objetivos e resultados encontrados nas pesquisas 


\begin{tabular}{|c|c|c|}
\hline ID & Objetivos do estudo & Resultados Encontrados \\
\hline A1 & $\begin{array}{l}\text { Identificar as principais } \\
\text { características de uma ação } \\
\text { eficaz de marketing boca a boca } \\
\text { virtual. }\end{array}$ & $\begin{array}{l}\text { Foram apontados seis fatores que podem influenciar o sucesso do marketing } \\
\text { boca a boca virtual: familiaridade com a marca da empresa que realiza a ação } \\
\text { de marketing viral, desenvolvimento de uma massa crítica de amplificadores } \\
\text { da mensagem, baixa complexidade da mensagem, existência de incentivos } \\
\text { para a replicação da mensagem, componente de diversão da mensagem e } \\
\text { imediatismo da ação de marketing viral. }\end{array}$ \\
\hline A2 & $\begin{array}{l}\text { Estudar como o site YouTube } \\
\text { tem sido utilizado por uma } \\
\text { conhecida marca de refrigerante } \\
\text { como uma eficiente ferramenta } \\
\text { de promoção de marketing. }\end{array}$ & $\begin{array}{l}\text { A comunicação viral tem se tornado mais eficiente e barata em transmitir a } \\
\text { mensagem ao público que os meios convencionais de comunicação, sendo } \\
\text { uma poderosa ferramenta de promoção, além de o YouTube ter uma forte } \\
\text { característica viral pelo fato de ser formado principalmente por } \\
\text { consumidores. }\end{array}$ \\
\hline A3 & $\begin{array}{l}\text { Desenvolver um método para a } \\
\text { otimização dos esforços de } \\
\text { comunicação e vendas em meio } \\
\text { eletrônico, baseando-se no } \\
\text { conceito de algoritmos } \\
\text { genéticos. }\end{array}$ & $\begin{array}{l}\text { Os consumidores apreciam mensagens personalizadas e tem resistência às } \\
\text { ações massivas das empresas. O método foi validado, apresentado em } 12 \\
\text { passos e resultando em uma taxa de clicagem de } 13,3 \% \text {, valor bem acima do } \\
\text { que a literatura apresenta habitualmente, indicando sua potencialidade de } \\
\text { utilização gerencial. }\end{array}$ \\
\hline A4 & $\begin{array}{l}\text { Apontar como as empresas } \\
\text { devem trabalhar o conteúdo de } \\
\text { suas campanhas on-line para que } \\
\text { suas mensagens publicitárias } \\
\text { sejam mais propagadas, } \\
\text { considerando como público-alvo } \\
\text { jovens residentes em Belo } \\
\text { Horizonte. }\end{array}$ & $\begin{array}{l}\text { Deve-se procurar ressaltar informações sobre o produto, criar mensagens } \\
\text { alegres e/ou que causem surpresa, informando e auxiliando os receptores, } \\
\text { que tenham o incentivo de familiares e amigos para ser propagada. O } \\
\text { marketing viral possibilita a comunicação entre a empresa e a comunidade. }\end{array}$ \\
\hline A5 & $\begin{array}{l}\text { Descrever estratégias de } \\
\text { comunicação de fabricantes de } \\
\text { alimentos com crianças na } \\
\text { mídia internet. }\end{array}$ & $\begin{array}{l}\text { Os fabricantes utilizam cada vez mais a internet como mídia para comunicar- } \\
\text { se com consumidores mirins, aos quais buscam comercializar, em sua } \\
\text { maioria, produtos pouco saudáveis, fazendo uma ligação entre jogos para } \\
\text { entretenimento e a criação de afeto pela marca. Além disso, buscam oferecer } \\
\text { downloads de arquivos que remetam à marca mesmo após a experiência on- } \\
\text { line, utilizando estratégias de marketing viral aliados às promoções de } \\
\text { vendas. Não existe nenhum alerta para as crianças sobre as intenções de } \\
\text { propaganda. }\end{array}$ \\
\hline A6 & $\begin{array}{l}\text { Verificar estratégias que podem } \\
\text { aumentar a pontuação de } \\
\text { influência nas redes sociais, por } \\
\text { meio de diferentes sistemas } \\
\text { baseados em algoritmos. }\end{array}$ & $\begin{array}{l}\text { As estratégias utilizadas consistem em seguir apenas os usuários que seguem } \\
\text { de volta os bots e tweets postados sobre tópicos populares e de grande foco. } \\
\text { Desta forma, verificou-se que o principal objetivo dos usuários da rede é } \\
\text { apenas aumentar seu próprio nível de influência, o que aponta que esses } \\
\text { sistemas devem rever seus algoritmos de pontuação de influência. }\end{array}$ \\
\hline A7 & $\begin{array}{l}\text { Analisar o impacto de } \\
\text { diferentes tipos de conteúdo no } \\
\text { marketing viral, em uma rede } \\
\text { social virtual bastante popular. }\end{array}$ & $\begin{array}{l}\text { Encontrou-se um relacionamento positivo entre postagens das categorias "fã" } \\
\text { e "promocional" com o marketing viral. Postagens das categorias } \\
\text { "informacional" e "enquete" não produziram efeitos significativos, } \\
\text { confirmando estudos anteriores que analisaram curtidas e comentários como } \\
\text { variáveis dependentes. }\end{array}$ \\
\hline A8 & $\begin{array}{l}\text { Identificar quais são as } \\
\text { características dos vídeos que } \\
\text { distinguem anúncios virais } \\
\text { bem-sucedidos e malsucedidos. }\end{array}$ & $\begin{array}{l}\text { Os resultados mostram que engajamento e surpresa são as duas principais } \\
\text { características que aumentam significativamente as chances de anúncios de } \\
\text { vídeo on-line se tornem virais. }\end{array}$ \\
\hline
\end{tabular}

Fonte: Elaborado pelos autores

A partir dos objetivos e resultados evidenciados no Quadro 2, elaborou-se um quadroresumo com os principais achados encontrados nos artigos analisados, sendo estes apresentados no Quadro 3 a seguir. 


\begin{tabular}{|c|l|}
\hline \multirow{4}{*}{$\begin{array}{c}\text { Quadro 3 - Quadro-resumo de achados dos artigos } \\
\text { MARKETING } \\
\text { VIRAL }\end{array}$} & $\begin{array}{l}\text { Baixa complexidade das mensagens e replicação do conteúdo em alta velocidade (A1); } \\
\text { Comunicação virtual mais eficiente e barata que os meios convencionais, possibilitando a } \\
\text { interação entre empresa e comunidade (A2; A4; A5); }\end{array}$ \\
\cline { 2 - 3 } & $\begin{array}{l}\text { Resistência às ações de Marketing Tradicionais (A3); } \\
\text { Mensagens de entretenimento e personalizadas (A3; A5); }\end{array}$ \\
\cline { 2 - 3 } & Usuários buscam aumentar sua influencia e melhorar sua imagem (A6); \\
\cline { 2 - 3 } & Retribuição de interações on-line, onde curtidas e comentários estão ligadas (A6; A7; A8). \\
\hline
\end{tabular}

Fonte: Elaborado pelos autores

Os artigos demonstram que para serem virais, os conteúdos devem ser compostos por mensagens de engajamento, pouco complexas, devem surpreender seu público-alvo, oferecer entretenimento, divertindo e alegrando seus receptores. Sua essência está na disseminação em alta velocidade, de maneira exponencial, observando que o principal objetivo no momento da replicação deste conteúdo pelos usuários é aumentar sua própria influência e imagem positiva, sendo que o sucesso destas interações está na estratégia de retribuição de curtidas e comentários on-line.

Desta maneira, é uma grande oportunidade para as empresas a utilização da comunicação viral, pois o perfil de consumidor atual não está aberto às ações de marketing massivas, resultando em grande resistência às mídias tradicionais. $\mathrm{O}$ marketing viral é a estratégia mais eficiente e barata de divulgar marcas e interagir com a comunidade de forma positiva e lucrativa.

\section{Conclusões}

O objetivo geral deste estudo foi apresentar um panorama da produção científica sobre o marketing viral por meio da biblioteca eletrônica Spell, analisando todos os artigos já publicados até agosto de 2018. Utilizou-se o método exploratório, realizando uma pesquisa bibliográfica, analisando de maneira qualitativa os artigos resultantes desta pesquisa e utilizando como ferramenta a bibliometria. O tema abordado é relativamente novo e pouco explorado, tendo em vista que a pesquisa resultou em apenas oito artigos, sendo que $75 \%$ deles foram publicados nos últimos cinco anos.

Para a construção destes artigos, os autores utilizaram as revistas em quase metade de suas fontes bibliográficas, os livros representaram mais de um quarto das referências, sites da web também obtiveram presença significativa, posteriormente foram utilizados eventos, dissertações e teses, em quantidades menos representativas. Considerando os métodos de pesquisa, a maior incidência foi de pesquisas exploratórias em caráter quantitativo, com aplicação de survey. Para a coleta de dados, houve um equilíbrio na utilização de dados secundários, questionários e observação, quando que a entrevista e coleta via internet obtiveram ocorrências únicas.

Em metade dos artigos analisados, a elaboração dos estudos foi realizada com a participação de duas instituições e em segundo plano os artigos foram formulados por uma única instituição, sendo que das onze instituições envolvidas, nove delas obtiveram sua primeira participação em artigos com esta temática, representando $82 \%$ de participações inéditas. Como sugestão, pode-se dar continuidade aos estudos na área do marketing viral, tanto por estas quanto por novas instituições, considerando os poucos estudos até então, a relevância do tema para a permanência de empresas no mercado e sua ascensão global, 
trazendo evolução no atendimento aos consumidores e suas demandas, criando relações afetivas com a marca, interagindo com a comunidade e seus anseios.

Como resultado final e grande contribuição, este trabalho identificou características essenciais do marketing viral unindo os conhecimentos gerados nos artigos estudados. Foi possível destacar a importância do marketing viral para a longevidade das organizações, considerando a tendência de conectividade mundial e os custos reduzidos desta estratégia de promoção. Apurou-se que o engajamento é fruto de uma série de características como o despertar de emoções de surpresa e alegria em seus receptores, oferecendo entretenimento com pouca complexidade. Ainda assim, definiu-se a grande motivação dos usuários para o compartilhamento: busca pelo reconhecimento da sociedade em que está inserido com o objetivo de aprimorar positivamente sua imagem e influência.

Tais achados refletem em grandes implicações gerenciais para as organizações, visto o crescente investimento das empresas em mídias digitais e o volume cada vez maior de consumidores conectados à internet. Além disso, este estudo aponta as características pelas quais os usuários da internet são cativados pelas marcas e engajados a compartilhar seus conteúdos, guiando os gestores de empreendimentos pelo caminho do marketing viral assertivo. 


\section{REFERÊNCIAS}

ALMEIDA, Marcos Inácio Severo de; COSTA, Milena; COELHO; Ricardo Limongi França; SCALCO, Paulo Roberto. "Engaja-me e atraia-me, então eu compartilharei": uma análise do impacto da categoria da postagem no marketing viral em uma rede social. São Paulo: RBGN Revista Brasileira de Gestão de Negócios, v. 18, n. 62, p. 545-569, 2016.

ARAÚJO, Carlos Alberto. Bibliometria: evolução histórica e questões atuais. Em Questão, v.12, n. 1, p. 11-32, 2006.

ARCOS, Virginia Aguilar; GUTIÉRREZ, Sonia San Martin; HERNANZ, Rene Payo. La aplicación empresarial del marketing viral y el efecto boca-oreja electrónico. Opiniones de las empresas. Cuadernos de Gestión, v. 14, n. 1, p. 15-31, 2014.

BAGCHI, Moinak; MURDOCH, Sonja; SCANLAN, Jay. The state of global media: spending. New York: McKinsey \& Company, 2015. Disponível em: https://www.mckinsey.com/industries/media-and-entertainment/our-insights/the-state-ofglobal-media-spending Acesso em: 18 dez. 2017.

BENTIVEGNA, Fernando Jucá. Fatores de impacto no sucesso do marketing boca a boca online. RAE - Revista de Administração de Empresas, v. 42, n. 1, p. 79-87, 2002.

BERGER, Jonah. Contágio - Por que as coisas pegam? São Paulo: Ed. Texto Editores, 2014.

BERGER, Jonah; MILKMAN, Katherine L. What makes online content viral?

Journal of Marketing Research, v. 49, n. 2, p. 192-205, 2012.

BORGES, Fábio Roberto Ferreira; GONÇALVES, Carlos Alberto; VEIGA, Ricardo Teixeira; GOSLING, Marlusa; FERNANDES, Izabella Bueno. Elaboração e experimento de um método de marketing viral e database marketing baseado em algoritmos genéticos. Revista Gestão \& Tecnologia, v. 12, n. 1, p. 151-175, 2012.

BOTHA, Elsamari, REYNEKE, Mignon. To share or not to share: the role of content and emotion in viral marketing. Journal of Public Affairs, v. 13, n. 2, p. 160-171, 2013.

CASARIN, Helen de Castro Silva. Pesquisa científica: da teoria à prática. Curitiba: Intersaberes, 2012.

CASTRO, Gisela Grangeiro da Silva. Entretenimento, sociabilidade e consumo nas redes sociais: cativando o consumidor-fã. Revista Fronteiras - estudos midiáticos, v. 14, n. 2, 2012.

COOPER, Donald R.; SCHINDLER, Pamela S. Business research methods. 12 ed. New York: McGraw-Hill Irwin, 2013. 
DARAYA, Vanessa. Cientistas resolvem problema do marketing viral. São Paulo: Revista Exame, 2013. Disponível em: https://exame.abril.com.br/ciencia/cientistas-resolvemproblema-do-marketing-viral/ Acesso em: 15 nov. 2017.

ECKERT, Alex. Marketing Virtual: conduzindo um empreendimento on-line ao sucesso. Curitiba: Prismas, 2017.

FRANCISCO, Eduardo de Rezende. RAE-eletrônica: exploração do acervo à luz da bibliometria, geoanálise e redes sociais. Revista de Administração de Empresas, v. 51, n. 3, p. 280-306, 2011.

GIL, Antônio Carlos. Como elaborar projetos de pesquisa. 5 ed. São Paulo: Atlas, 2010.

HO, Jason Y.C.; DEMPSEY, Melanie. Viral marketing: motivations to forward online content. Journal of Business Research. v. 63, n.1, 2010.

HUERTAS, Melby Karina Zuniga; URDAN, André Torres; ADACHI, Patricia Podboi; GOMES, Silvia Cressoni. Comunicações de marketing de fabricantes de alimentos: quando o alvo são crianças e a mídia internet. Revista Gestão \& Tecnologia, v. 12, n. 3, p. 79-102, 2012.

KNOSSENBURG, Yentl Lisanne; NOGUEIRA, Roberto; CHIMENTI, Paula. Contagious content: viral video ads identification of content characteristics that help online video advertisements go viral. ReMark - Revista Brasileira de Marketing, v. 15, n. 4, p. 448-458, 2016.

KOTLER, Philip; KARTAJAYA, Hermawan; SETIAWAN, Iiwan. Marketing 3.0: as forças que estão definindo o novo marketing centrado no ser humano. Rio de Janeiro: Elsevier, 2010.

KOTLER, Philip; KARTAJAYA, Hermawan; SETIAWAN, Iiwan. Marketing 4.0: do tradicional ao digital. Rio de Janeiro: Sextante, 2017.

LAM, Camila. O que aprender com 10 campanhas de marketing viral. São Paulo: Revista Exame, 2013. Disponível em: https://exame.abril.com.br/pme/o-que-aprender-com-10campanhas-de-marketing-viral/ Acesso em: 22 out. 2017.

LIRA, Adriano. Os 8 Ps do marketing digital para fazer sucesso na internet. Revista Pequenas Empresas \& Grandes Negócios. Publicado em: 12 ago. 2016. Disponível em: http://revistapegn.globo.com/Empreendedorismo/noticia/2016/08/os-8-ps-do-marketingdigital-para-fazer-sucesso-na-internet.html Acesso em: 08 set. 2017.

MALHOTRA, Naresh K. Pesquisa de marketing: uma orientação aplicada. 6 ed. Porto Alegre: Bookman, 2012.

MANS, Matheus. 'Existe uma ciência por trás do conteúdo viral' afirma especialista. O Estado de São Paulo: 04 ago. 2017. Disponível em: http://link.estadao.com.br/noticias/cultura-digital,existe-uma-ciencia-por-tras-do-conteudoviral-afirma-especialista,70001923344 Acesso em: 14 nov. 2017. 
MESSIAS, Johnnatan; SCHMIDT, Lucas; OLIVEIRA, Ricardo; BENEVENUTO, Fabrício. Bots sociais: como robôs podem se tornar influentes no Twitter. Revista Eletrônica de Sistemas de Informação, v. 14, n. 2, 2015.

PEREIRA, Thiago Carvalho; CRUZ, Eduardo Picanço. O uso do Youtube como ferramenta de marketing: o caso Guaraná Antarctica. Revista Pensamento Contemporâneo em Administração, v. 3, n. 2, p. 1-19, 2009.

PEROVANO, Dalton Gean. Manual de metodologia de pesquisa científica. Curitiba: Intersaberes, 2016.

PINHEIRO, Duda; GULLO, José. Comunicação integrada de marketing: gestão de elementos de comunicação. 4 ed. São Paulo: Atlas, 2013.

REICHELT, Valesca Persch. Fundamentos de marketing. Curitiba: InterSaberes, 2013.

RIBEIRO, Henrique César Melo. Revista contemporânea de contabilidade: uma análise do perfil da produção acadêmica durante o período de 2004 a 2012. Revista Contemporânea de Contabilidade, v. 10, n. 20, p. 03-28, 2013.

RODGERS, Shelly; THORSON, Esther. Digital advertising: theory and research. 3 ed. Abingdon: Routledge, 2017.

SOLOMON, Michael R. O comportamento do consumidor: comprando, possuindo e sendo. 9 ed. Porto Alegre: Bookman, 2011.

SOUZA, Gustavo Ferreira Mendes de; BORGES, Fábio Roberto Ferreira; LOPES, Ana Lucia Miranda; MUNIZ, Reynaldo Maia. Propagação de mensagens na internet: teoria do comportamento planejado. Revista Pretexto, v. 13, n. 3, p. 11-27, 2012.

SOUZA, Márcio Vieira de; GIGLIO, Kamil. Mídias digitais, redes sociais e educação em rede: experiências na pesquisa e extensão universitária. São Paulo: Blucher, 2015.

SPELL - Scientific Periodicals Eletronic Library. Objetivos. Disponível em: http://www.spell.org.br/sobre/objetivos Acesso em: 15 ago. 2018.

TORRES, Cláudio. Guia prático de marketing na internet para pequenas empresas: dicas para posicionar o seu negócio e conquistar novos clientes na internet. 2010. Disponível em: http://www.cairu.br/biblioteca/arquivos/Marketing/ Acesso em: 08 set. 2017.

VALENTE, Jonas. Relatório aponta Brasil como quarto país em número de usuários de internet. Brasília: Empresa Brasil de Comunicação S/A - EBC, 2017. Publicado em: 03 out. 2017. Disponível em: http://agenciabrasil.ebc.com.br/geral/noticia/. Acesso em: 13 dez. 2017.

VAZ, Conrado Adolpho. Os 8 Ps do marketing digital: o guia estratégico de marketing digital. São Paulo: Novatec Editora, 2011. 